\title{
Business Tax Burdens and Tax Reform
}

ABSTRACT Tax reforms affect economic performance by changing incentives for business formation, expansion, and operation. The United States has the highest corporate tax rate among countries with advanced economies, and-despite offering significant additional deductions, exclusions, and tax credits-it imposes the heaviest tax burdens. This paper offers a new measure of corporate tax burdens based on information in tax expenditure budgets; this measure implies that the burden of U.S. corporate taxation in 2017 is equivalent to that produced by a corporate tax rate of between 31.7 and 34.8 percent, without additional deductions, exclusions, or tax credits. Efficient design of a business tax system encourages activities with beneficial economic spillovers and imposes lighter burdens on those industries and activities that are most responsive to taxation. Tax reforms have the potential to improve economic efficiency by adjusting the level and design of U.S. business taxes.

B usiness taxes in the United States and elsewhere raise revenue at the cost of discouraging business activity, a tension that lies inescapably at the heart of any business tax policy. A near-universal characteristic of governments is that they desire strong economies, for which they rely on businesses as drivers. Governments also need to finance their expenditures. It is possible to improve a country's economic outcomes without sacrificing business tax revenues by restructuring its business taxes in a revenue-neutral way that improves efficiency by better aligning production incentives with economic costs and returns and that directs tax burdens to where they have the least harmful effects on aggregate economic activity. There is, however, a natural limit to the effectiveness of any such reform

Conflict of Interest Disclosure: The author is research director for the International Tax Policy Forum, which as an organization does not advocate for particular policies. The author did not receive financial support from any firm or person for this paper or from any firm or person with a financial or political interest in this paper. With the exception of the aforementioned, he is currently not an officer, director, or board member of any organization with an interest in this paper. No outside party had the right to review this paper before publication. 
strategy, because business taxes by their very nature depress incentives for business formation and expansion.

An alternative and possibly supplementary method of encouraging business activity would be to reduce business taxes and replace the lost revenue with other taxes, while strengthening measures to prevent personal income from being reclassified as tax-favored business income. But quite apart from the difficulty of preventing tax avoidance by reclassifying income, and the unattractiveness of any replacement taxes, such a course would run into another common constraint on democratic policymaking: the political importance of appearing to impose significant tax burdens on businesses. Of course, the notion of actually imposing a tax burden on business is illusory, because the burdens of business taxes are in fact borne by combinations of individuals - business owners, domestic workers and consumers, and possibly foreigners - rather than by business entities per se. And as a method of raising tax revenue, many business taxes are considerably less efficient and equitable than other tax alternatives that are within the power of governments to enact. But some combination of the difficulty of legislative compromise, prevailing uncertainty over who actually bears the burden of business taxes, and the powerful if misleading imagery of taxing large, affluent business organizations creates sufficiently compelling political imperatives for heavy and distortionary business entity taxation to persist in some countries, notably including the United States, despite these taxes' economic consequences.

Much of the international experience differs from that of the United States. In recent decades, most high-income countries other than the United States have significantly lowered their corporate tax rates, and many have dramatically reduced or eliminated their taxation of foreign business income, introduced special tax regimes for income produced by intellectual property, and generally sought to reduce business tax burdens. These efforts are intended to stimulate local economies by encouraging business formation and expansion, and to put countries in strong positions to compete for internationally mobile business activity and income. It is noteworthy that these business tax reductions have been enacted by foreign governments of all political persuasions. Yet the United States continues to tax worldwide business income, has not reduced its statutory corporate tax rate since 1986, and since 1986 has significantly increased the personal income tax rates at which unincorporated businesses and $\mathrm{S}$ corporations are taxed. Although the United States has in the meantime introduced some business tax incentives, including rapid write-offs of new business investment and favorable treatment of income from domestic manufacturing, the 
relatively minor economic significance of these incentives compared with significant foreign tax reductions has made the United States a comparatively much less attractive tax environment for business activity.

There is widespread, and to some degree bipartisan, concern that the 2017 business tax environment adversely affects the U.S. economy by making the United States a relatively unattractive location for internationally mobile business headquarters and investment, and by imposing distortionary and excessively heavy burdens on the businesses that remain legally based in the United States. Of course, there is far from a consensus on the nature and features of beneficial reforms that the country might adopt. Proposed reforms can be evaluated on two dimensions: their effects on total business tax burdens, and their effects on the efficiency of resource allocation at any given level of aggregate business tax burden. It is noteworthy that proposed reforms also generally fall into two categories: those that would reduce total business tax burdens, and those that would restructure business taxes without much changing aggregate burdens, typically by reducing statutory tax rates while expanding business tax bases. Many proposed reforms of both types would include having the United States adopt a territorial tax system that largely or entirely exempts foreign business income from U.S. taxation.

Business tax reductions are logical reactions to heavy aggregate U.S. tax burdens; but as a design feature, or perhaps as a concession to political concerns, the reductions in entity-level business tax burdens can be buried in proposal details. The 2016 House Republican tax reform plan for a destination-based corporate cash-flow tax effectively introduces a significantly modified value-added tax and uses the revenues that this tax generates to finance reduced corporate tax rates and a narrowing of the corporate income tax base. Separate corporate tax integration proposals would increase U.S. shareholder taxes on dividends (and possibly capital gains) while reducing U.S. business entity-level taxes by, for example, permitting deductions for dividends paid to shareholders. These tax integration proposals redirect a portion of the burden of equity-financed investment from firms to dividend recipients, in the process reducing entity-level business taxes.

An alternative reform strategy is to maintain tax collections from business entities at roughly their current levels, but to reduce statutory business tax rates while expanding business tax bases. Examples include President Obama's proposed budgets, which would have reduced the statutory U.S. corporate tax rate, implemented a form of territorial taxation, and limited certain business deductions. The primary goal of such proposed reforms is to address adverse incentives caused by high statutory tax rates. Of course, 
statutory tax rate reductions that are financed with tax base expansions cannot improve incentives for all business activities, because incentives are products of marginal tax rates, and it is impossible to reduce all marginal business tax rates while keeping average business tax rates unchanged. ${ }^{1}$ Consequently, if business tax reform is to be revenue-neutral within the business sector, then it will encourage some business activities and discourage others; a statutory tax rate reduction financed with reduced tax deductions and credits will discourage activities that previously benefited disproportionately from the deductions and credits while encouraging activities that did not. It is certainly possible to improve the efficiency of business taxes this way; but there is a strict limit on the extent to which it is thereby possible to reduce total business tax burdens and consequently improve incentives for business activity as a whole.

Section I of this paper considers the burden of U.S. business taxes, introducing a new measure of corporate tax burdens that offers additional evidence of the extent to which U.S. corporate taxes exceed those of other high-income countries. Section II considers efficient business tax design, with implications for proposed tax reforms.

\section{U.S. Business Tax Burdens}

Available measures commonly suggest that U.S. businesses in 2017 face tax burdens that exceed those of almost all—and possibly all—other countries. One challenge in ranking the relative tax burdens of different countries is that no single measure offers an entirely reliable or compelling metric by which to compare tax systems. The most easily accessible comparative guide is provided by statutory corporate tax rates. Because countries differ in the extent to which subnational governments levy business taxes, it is important to incorporate subnational taxes when comparing them. The Organization for Economic Cooperation and Development (OECD) reports combined national and average subnational corporate tax rates for the 35 OECD member countries; table 1 displays these 2017 tax rates from highest to lowest. The United States appears prominently at the top of the list, with an average 38.91 percent tax rate; France is a distant second, at 34.43 percent; ${ }^{2}$ Belgium is third, at 33.99 percent; Germany is

1. If a reform could introduce new lump-sum taxes, then it would be possible to lower all marginal tax rates while maintaining average tax rates unchanged; but the realistic scope of any such lump-sum taxation is extremely limited.

2. It is noteworthy that the French government has enacted a phased future reduction in its corporate tax rate. 
Table 1. Statutory Combined Corporate Income Tax Rates for the OECD Countries, 2017

\begin{tabular}{lclc}
\hline Country & Tax rate (percent) & Country & Tax rate (percent) \\
\hline United States & 38.91 & Israel & 24 \\
France & 34.43 & Norway & 24 \\
Belgium & 33.99 & Denmark & 22 \\
Germany & 30.18 & Sweden & 22 \\
Australia & 30 & Switzerland & 21.15 \\
Mexico & 30 & Slovakia & 21 \\
Japan & 29.97 & Estonia & 20 \\
Portugal & 29.5 & Finland & 20 \\
Greece & 29 & Iceland & 20 \\
New Zealand & 28 & Turkey & 20 \\
Italy & 27.81 & Czech Republic & 19 \\
Luxembourg & 27.08 & Poland & 19 \\
Canada & 26.7 & Slovenia & 19 \\
Austria & 25 & United Kingdom & 19 \\
Chile & 25 & Latvia & 15 \\
Netherlands & 25 & Ireland & 12.5 \\
Spain & 25 & Hungary & 9 \\
South Korea & 24.2 & & \\
\hline
\end{tabular}

Source: OECD tax database.

fourth, at 30.18 percent; and the 31 remaining OECD countries have tax rates of 30 percent or below, notably including Canada (26.7 percent) and the United Kingdom (19 percent).

As judged by statutory corporate tax rates, the United States clearly has the highest business tax burden among the OECD countries in 2017. But there is an understandable concern that statutory tax rates fail to capture important aspects of tax systems, and thus are potentially misleading guides to comparative tax burdens. Business tax systems differ in the degrees to which they feature favorable deductions, tax credits, exclusions, and other provisions designed to encourage specific business activities. These provisions serve to mitigate tax burdens, thereby subjecting businesses to effective levies that can be significantly lower than those suggested by headline tax rates. Furthermore, savvy taxpayers commonly structure their firms and their business transactions to benefit from available tax deductions and credits.

\section{I.A. Estimating Burden-Equivalent Tax Rates}

It is possible to use estimates of the value of favorable tax provisions to modify statutory corporate tax rates so as to construct burden-equivalent 
corporate tax rates-rates that reflect the tax burdens imposed on corporations net of any favorable tax deductions, income exclusions, and tax credits. Because these burden-equivalent tax rates incorporate the values of special tax provisions, they can be used to assess relative corporate tax burdens. Many governments publish what are known as tax expenditure budgets, which consist of estimates of tax revenue forgone by legislated deviations from what would otherwise have been standard taxation. By far the largest U.S. corporate tax expenditure in 2017 is that for the deferral of U.S. taxation of unrepatriated foreign income ( $\$ 123.2$ billion); the nextlargest individual items are accelerated depreciation of equipment investment ( $\$ 28.6$ billion), the favorable treatment of research and development expenditures ( $\$ 16.5$ billion), and the domestic production activities deduction (\$12.1 billion). ${ }^{3}$

Tax expenditure budgets were introduced by the United States (Surrey 1973), and many of their applications are highly controversial, because the magnitudes of estimated tax expenditures depend critically on what one takes to be a standard tax system. For example, the tax expenditure associated with the deferral of U.S. taxation of foreign income presumes that in a standard tax system, the United States would tax the foreign incomes of its resident companies, which was once common practice but is now very unusual among high-income countries. Similarly, the tax expenditure amount for accelerated tax depreciation of capital investment depends on the counterfactual-the tax depreciation provisions that would constitute a normal tax system, about which there is considerable disagreement. Despite these and other concerns about tax expenditure budgets, they provide information that can be readily used to modify statutory tax rates, particularly because governments conveniently distinguish corporate from noncorporate tax expenditures.

To use tax expenditure information to construct burden-equivalent tax rates, it is necessary to distinguish tax expenditures such as generous expense deductions that narrow the tax base from those such as tax credits that do not. Base-narrowing tax expenditures reduce the impact of high statutory tax rates, because a statutory rate of 30 percent applied to just 80 percent of income is equivalent to one of 24 percent applied to all

3. The tax expenditure figure for accelerated depreciation is the difference between taxes collected in 2017 and the amount that would have been collected with tax depreciation rules in an idealized income tax. This is not the same as the present value of the implied tax benefit for investment undertaken in 2017, though there are circumstances in which the two concepts would produce the same estimate. 
income. The interaction of the tax base and statutory rates means that it is not possible to construct a burden-equivalent corporate tax rate simply by multiplying the statutory corporate tax rate by the ratio of corporate tax revenue to the sum of corporate tax revenue and corporate tax expenditures, because it is necessary to adjust tax rates for the width of the tax base. Furthermore, it is necessary to adjust burden-equivalent tax rates for the costs that taxpayers incur in arranging their business affairs to benefit from tax expenditures.

It is useful to consider a simple formulation in which a representative firm is subject to tax at rate $\tau$, has gross income of $y$, and has three categories of expenses, $x_{1}, x_{2}$, and $x_{3}$. All expenses are fully deductible from taxable income; and, in addition, the firm is permitted an extra tax deduction equal to a fraction $\alpha$ of expense of type $3 .{ }^{4}$ The firm can also claim a tax credit for a fraction $k$ of its expenditures on $x_{2}$. The firm's after-tax profits $(\pi)$ are

$$
\pi=(1-\tau)\left(y-x_{1}-x_{2}-x_{3}\right)+\tau \alpha x_{3}+k x_{2} .
$$

Total tax revenue is $\tau\left[y-x_{1}-x_{2}-(1+\alpha) x_{3}\right]-k x_{2}$, and total tax expenditures are $\left(\tau \alpha x_{3}+k x_{2}\right)$. Differentiating the determinants of $\pi$ with respect to the tax parameters $\tau, \alpha$, and $k$, and applying Shephard's lemma, it follows that

$$
\begin{gathered}
\frac{\partial \pi}{\partial \tau}=-\left[y-x_{1}-x_{2}-(1+\alpha) x_{3}\right], \\
\frac{\partial \pi}{\partial \alpha}=\tau x_{3}, \\
\frac{\partial \pi}{\partial k}=x_{2} .
\end{gathered}
$$

The goal in measuring a burden-equivalent tax rate $\hat{\tau}$ is to determine the value of $\tau$ that, if applied to pretax profits without an extra deduction for $x_{3}$ or a tax credit for $x_{2}$, would produce a tax burden equivalent to the

4. Some corporate tax expenditures, such as the U.S. domestic production activities deduction, take the form of excluding portions of income from taxation. Income exclusions narrow the tax base in a manner analogous to extra expense deductions, so the analysis of base-narrowing expense deductions in equations 1 through 9 applies equally to income exclusions. 
existing tax system. One can think of first removing the extra tax deduction $\alpha$ while simultaneously reducing the corporate tax rate to keep the firm's total tax burden unchanged, thereby producing an intermediate value $\tau^{*}$ to accompany $\alpha=0$. Denoting by $\frac{\partial \hat{\tau}^{c}}{\partial \alpha}$ the change in $\tau$ needed to accompany a small change in $\alpha$ while keeping firm profits constant, it follows from equations $2 \mathrm{a}$ and $2 \mathrm{~b}$ that

$$
\frac{d \tau^{c}}{d \alpha}=\frac{\tau x_{3}}{y-x_{1}-x_{2}-(1+\alpha) x_{3}} .
$$

Analogously, equations $2 \mathrm{a}$ and $2 \mathrm{c}$ together imply that for a corresponding change in tax credits and tax rates,

$$
\frac{d \tau^{c}}{d k}=\frac{x_{2}}{y-x_{1}-x_{2}-(1+\alpha) x_{3}} .
$$

A first-order approximation to the effect of removing $\alpha$ on the value of $\tau^{*}$ is $-\alpha \frac{d \hat{\tau}^{c}}{d \alpha}$, but one of the challenges of using equation 3 to estimate $\tau^{*}$ this way is that the magnitude of $\frac{d \hat{\tau}^{c}}{d \alpha}$ changes as $\alpha$ declines. A convenient second-order approach is to use an average of the values of $\frac{d \hat{\tau}^{c}}{d \alpha}$ taken before and after the removal of $\alpha$, from which it follows that

$$
\tau^{*} \approx \tau-\alpha\left\{\frac{\tau x_{3}}{2\left[y-x_{1}-x_{2}-(1+\alpha) x_{3}\right]}+\frac{\tau^{*} x_{3}^{*}}{2\left(y^{*}-x_{1}^{*}-x_{2}^{*}-x_{3}^{*}\right)}\right\}
$$

where $y^{*}, x_{1}^{*}, x_{2}^{*}$, and $x_{3}^{*}$ are values of these income and expense items when $\alpha=0$ and the tax rate is $\tau^{*}$. Equation 5 implies

$$
\tau^{*} \approx \tau \frac{1-\frac{\alpha x_{3}}{2\left[y-x_{1}-x_{2}-(1+\alpha) x_{3}\right]}}{1+\frac{\alpha x_{3}^{*}}{2\left(y^{*}-x_{1}^{*}-x_{2}^{*}-x_{3}^{*}\right)}} .
$$

It is possible to estimate bounds for the value of $\tau^{*}$ by applying assumptions about the determinants of the ratio that appears in the denominator on the right side of equation 6 . If economic behavior is unaffected by tax 
expenditures-the assumption that generally underlies government calculation of tax expenditure amounts-then the values of gross income and expenses in the denominator on the right side of equation 6 are the same as those in the numerator. This assumption is very unlikely to be true, because increasing the after-tax cost of $x_{3}$ while keeping total business tax burdens unchanged is likely to reduce the intensity with which a representative firm uses $x_{3}$; but the no-responsiveness assumption provides one bound for the value of $\tau^{*}$. The opposite-extreme assumption —and it is quite extreme-is that, in the absence of the additional tax deduction, firms would not use input $x_{3}$, so that $x_{3}^{*}=0$ and the denominator on the right side of equation 6 equals 1 . More realistically, one should expect an accurate value of $\tau^{*}$ to lie between those implied by these assumptions.

With $\tau^{*}$ available from equation $6, \hat{\tau}$ can be determined by using equation 4 to adjust the tax rate for removing the tax credit-which, using a method analogous to equation 5 , implies that

$$
\hat{\tau} \approx \tau^{*}-k\left[\frac{x_{2}^{*}}{2\left(y^{*}-x_{1}^{*}-x_{2}^{*}-x_{3}^{*}\right)}+\frac{x_{2}^{* *}}{2\left(y^{* *}-x_{1}^{* *}-x_{2}^{* *}-x_{3}^{* *}\right)}\right]
$$

where $y^{* *}, x_{1}^{* *}, x_{2}^{* *}$, and $x_{3}^{* *}$ are values of these income and expense items when $k=0$ and the tax rate is $\hat{\tau}$. In the extreme case in which behavior is assumed to be unaffected by tax preferences, the values of gross income and expense on the right side of equation 7 are those prevailing under the current tax system. In the opposite extreme case, in which $x_{3}^{*}$ is assumed to be 0 , it is also necessary to assume that $x_{2}^{* *}=0$, and that removing the tax credit eliminates the use of $x_{2}$. The only undetermined expression in equation 7 is the ratio $x_{2}^{*} /\left(y^{*}-x_{1}^{*}-x_{2}^{*}-x_{3}^{*}\right)$, which depends on the nature of the production function; this ratio is larger if $x_{2}$ and $x_{3}$ are substitutes in production (holding constant total business tax burdens, and therefore roughly holding output constant), and smaller if they are complements. Acknowledging that all productive inputs have at least some conditional substitutes, for the purpose of calculating an upper bound it is reasonable to take this ratio not to change as $x_{3}$ declines, again making the values of gross income and expense on the right side of equation 7 the same as those prevailing under the current tax system.

\section{I.B. Estimated U.S. Corporate Tax Burdens}

An extremely convenient feature of the system described by equations 6 and 7 is that the lower and upper bounds on $\hat{\tau}$ can be readily calculated using publicly reported data on corporate tax expenditures and 
revenues. Under the assumption that taxpayer behavior is unaffected by tax preferences, equations 6 and 7 together imply that the lower bound on, $\hat{\tau}$ denoted, $\hat{\tau}_{1}$ can be calculated as

$$
\hat{\tau}_{1}=\tau\left[\frac{1-\frac{T E-T C}{2(T R+T C)}}{1+\frac{T E-T C}{2(T R+T E)}}-\frac{T C}{T R+T E}\right],
$$

where $T E \equiv \tau \alpha x_{3}+k x_{2}$ is the aggregate value of corporate tax expenditures, $T C \equiv k x_{2}$ is the tax credit component of these expenditures, and $T R \equiv \tau\left[y-x_{1}-x_{2}-(1+\alpha) x_{3}\right]-k x_{2}$ is total corporate tax revenue. Similarly, the upper bound on $\hat{\tau}$, denoted $\hat{\tau}_{2}$, can be calculated as

$$
\hat{\tau}_{2}=\tau\left[1-\frac{T E-T C}{2(T R+T C)}-\frac{T C}{2(T R+T E)}\right] .
$$

To calculate $\hat{\tau}_{1}$ and $\hat{\tau}_{2}$ from equations 8 and 9 , it is necessary to use estimates of total corporate tax expenditures and the portion corresponding to tax credits. The U.S. Treasury reports corporate tax expenditures by category of tax provision, cautioning that its data are calculated one provision at a time and under the assumption that economic behavior does not respond to incentives created by tax expenditures. ${ }^{5}$ Because tax expenditures can have interacting effects on tax revenue, the total revenue effects of tax expenditures need not equal the sums of individual items. It is nonetheless informative to sum reported corporate tax expenditures to obtain an estimate of their total, though in so doing it is appropriate to exclude two categories of reported corporate tax expenditures. The first is the deferral of U.S. taxation of the unrepatriated foreign profits of U.S. firms. This item-which, as noted above, is by far the largest reported corporate tax expenditure-reflects taxes not collected because the United States, while imposing a worldwide tax system, does not do so on an accrual basis, instead taxing most foreign income only when repatriated. Most countries, including all other G-7 countries and all but a few other OECD countries, either exempt from tax the foreign incomes earned by their resident companies or else tax only trivial portions of

5. The Treasury's estimates of tax expenditures for various years can be found at https:// www.treasury.gov/resource-center/tax-policy/Pages/Tax-Expenditures.aspx. 
this income. These countries do not consider the failure to tax the foreign incomes of their resident companies to be tax expenditures; so in order to make a U.S. burden-equivalent tax rate internationally comparable, it is inappropriate to treat the deferral of foreign income as a tax expenditure.

The second modification is to exclude the tax expenditures for taxexempt state and local debt held by corporations and low-income housing tax credits claimed by corporations. ${ }^{6}$ It is well understood that the bond market prices tax-exempt debt in such a way that the vast majority of the tax benefit flows to issuing states and localities in the form of lower borrowing costs, whereas corporate holders of this debt receive reduced pretax returns and therefore only very small net benefits. Similarly, corporate claimants of low-income housing tax credits do so by making equity investments that effectively purchase the credits from housing developers at prices that largely reflect the associated tax benefits, so the benefits flow to developers, not corporate tax credit claimants. ${ }^{7}$ Although market forces limit the benefits of all tax expenditures by encouraging economic activity that reduces net returns, arbitrage by financial markets in the case of taxexempt bonds, and the active market for tax credits in the case of the lowincome housing tax credit, specifically limit corporate taxpayers' ability to benefit from these provisions.

Table 2 presents estimates of $\hat{\tau}_{1}$ and $\hat{\tau}_{2}$ for the United States for fiscal years 2005-17, along with underlying data on contemporaneous values of $T E, T C, T R$, and the U.S. combined federal and state statutory tax rate. ${ }^{8}$ Two facts are evident from the table. First, the burden-equivalent tax rates $\hat{\tau}_{1}$ and $\hat{\tau}_{2}$ are both significantly lower than the contemporaneous statutory corporate tax rates, and second, the burden-equivalent tax rates are nonetheless quite high. For fiscal year $2017, \hat{\tau}_{1}=31.7$ percent and

6. The tax expenditure for the exclusion of interest on state and local debt held by corporations was $\$ 8.4$ billion in 2017 , and the corporate tax expenditure for low-income housing tax credits was $\$ 8.3$ billion. Treating both these provisions as actual corporate tax benefits, and therefore adding them to aggregate corporate tax expenditures, would reduce the 2017 estimate of $\hat{\tau}_{1}$ from 31.7 to 30.6 percent, and reduce $\hat{\tau}_{2}$ from 34.8 to 34.2 percent.

7. See Jordan and Pettway (1985) on the pricing of municipal debt; and see Desai, Dharmapala, and Singhal (2010) on the pricing of low-income housing tax credits.

8. The calculations in table 2 implicitly treat average state corporate income tax systems as offering tax expenditures that are equivalent to federal tax expenditures; to the extent that this assumption overstates the value of state tax expenditures, this treatment produces estimated burden-equivalent tax rates that are slightly too low. 


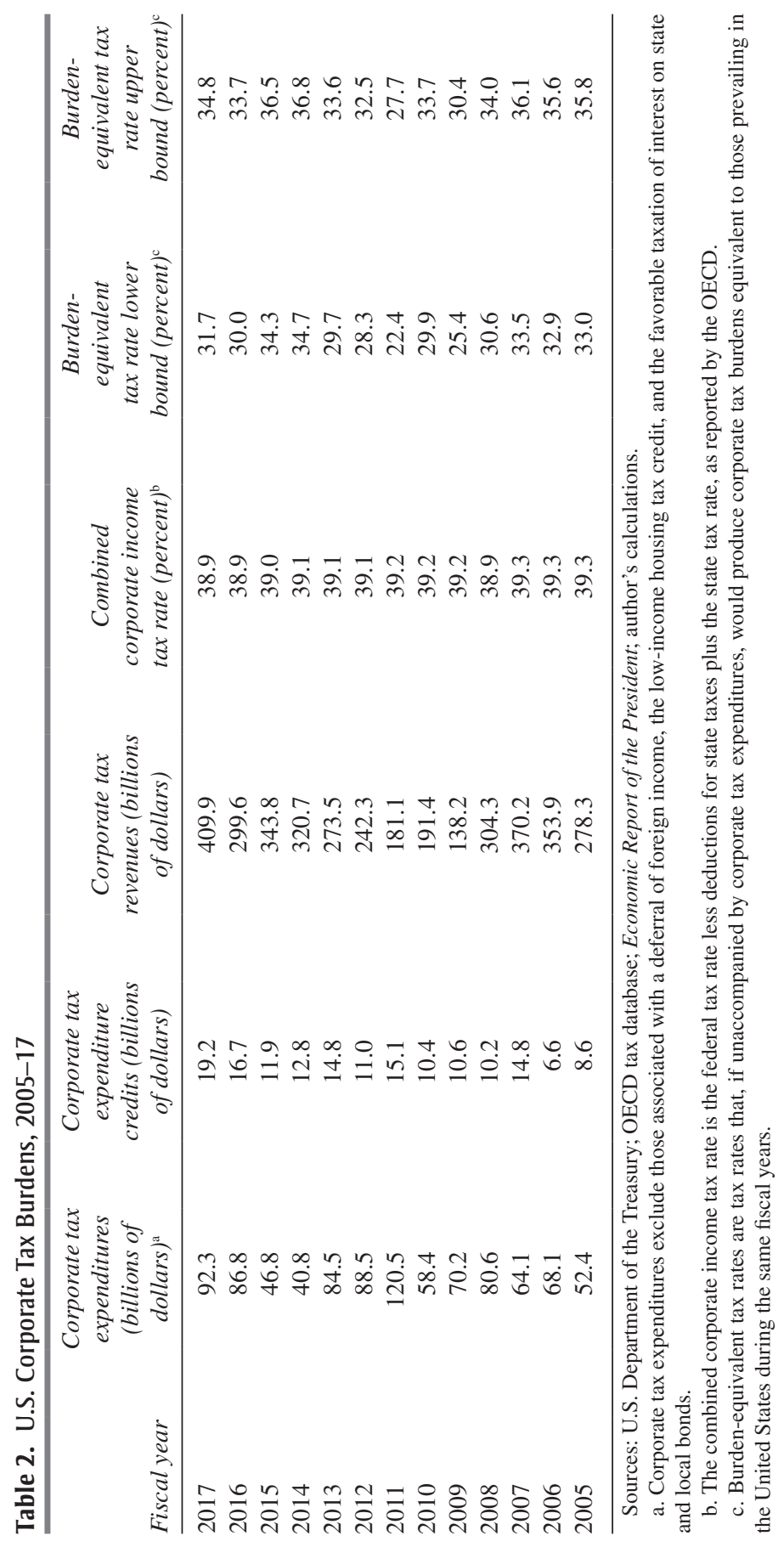


$\hat{\tau}_{2}=34.8$ percent, which suggests that the true burden-equivalent tax rate lies between these figures, likely closer to 31.7 percent than to 34.8 percent. If no other OECD country had any corporate tax expenditures, even a burden-equivalent tax rate of 31.7 percent would make the U.S. corporate tax system the third-most-burdensome of all the OECD countries. But of course the other OECD countries also offer their firms tax breaks of many types-including research credits, accelerated depreciation of capital investment, favorable taxation of certain categories of business income, and other provisions that in the United States would be classified as corporate tax expenditures. National differences in tax expenditure reporting concepts and practices (OECD 2010; Astarita and others 2014) make it extremely difficult to offer consistent calculations of foreign burden-equivalent tax rates that can be used for international comparisons, but it is nonetheless clear that the United States has a very high rate relative to other high-income countries.

Tax expenditure and corporate tax revenue data exhibit fluctuations between years and over business cycles that reflect annual accounting year concepts, transitory fluctuations, and other features that make these annual figures noisy measures of the long-run incentives created by corporate tax systems. For this reason, it is useful to consider the 2005-17 series of estimated burden-equivalent tax rates - the lower bound of which exceeds 29 percent in every year except for three of the four years following the crash of 2008 (when significant business tax incentives were introduced), and the upper bound of which exceeds 32 percent in all but two years. U.S. burden-equivalent corporate tax rates are consistently high because combined U.S. federal and state statutory tax rates are very high, and U.S. corporate tax expenditures, though certainly significant, are not large enough in magnitude to reduce U.S. tax burdens to the point that they would become comparable to the significantly lower corporate tax burdens of other countries. This is why it is infeasible to craft genuinely revenueneutral U.S. corporate tax reforms that would entail significantly reduced corporate tax rates.

U.S. corporate tax burdens are high despite efforts by U.S. corporations to avoid tax obligations in various ways-including investing in taxpreferred activities, such as research and development (R\&D), domestic manufacturing, and low-income housing; financing investments with debt rather than equity in order to obtain tax deductions for interest expenses; and locating profitable investments in low-tax locations, including foreign countries. Corporate tax avoidance is costly, as evidenced by the incompleteness of tax avoidance in practice and the empirical pattern that 
avoidance activity increases significantly as tax burdens grow. ${ }^{9}$ The costs of activities that facilitate tax avoidance-such as borrowing more than firms would otherwise want to; committing capital to low-return investments abroad or in domestic $\mathrm{R} \& \mathrm{D}$, manufacturing, or low-income housing projects; or engaging in other tax-preferred activities - are part of the burden of taxation; and these costs account for the differences between $\hat{\tau}_{1}$ and $\hat{\tau}_{2}$ in table 2. Moreover, the United States is not unique in this regard; corporations in other countries also avoid taxes, and incur costs in doing so. U.S. corporations that are subject to significantly higher burden-equivalent corporate tax rates than are corporations resident in the other OECD countries can therefore be expected to avoid taxes aggressively but nonetheless face the highest tax burdens.

\section{I.C. Other Evidence and Implications of U.S. Business Tax Burdens}

The high estimated burden-equivalent tax rates facing U.S. corporations are consistent with other measures of their relative tax burdens. The financial accounts of corporations based in different countries can be used to produce measures of effective corporate tax rates, which generally are defined as average ratios of tax obligations to pretax incomes. Kevin Markle and Douglas Shackelford (2012) consider financial statement information for publicly held multinational corporations based in 82 countries from 1988 to 2009, estimating the determinants of firms' worldwide average tax rates. After controlling for industry, year, and firm size, they find that a firm's national domicile is significantly associated with the average tax rates reported in its financial accounts, with Japanese multinational firms facing the highest average rates, and U.S. firms facing the secondhighest rates. This same pattern appears in 2006-11 data for 9,022 multinational firms based in 87 countries (Markle and Shackelford 2014). The evidence from Markle and Shackelford is consistent with the very high Japanese statutory tax rates in the earlier parts of their sample periods, and is also consistent with the Congressional Budget Office's (2017) calculations showing that ratios of taxes paid to pretax income are significantly higher for corporate operations in the United States than for operations in any other OECD country that belongs to the G-20.

9. For example, Graham (1996), Desai, Foley, and Hines (2004a, 2016), and others report that higher corporate tax rates are associated with greater U.S. corporate borrowing; and Graham (2000) calculates that U.S. corporations could double their tax benefits by borrowing more than they do. 
It can be difficult to interpret accounting-based comparisons of average tax rates, given that they are affected by endogenous business decisions. For example, a corporation that invests heavily in tax-favored assets, or is financed extensively with debt, will appear to have a lower average tax rate than a corporation that does not, even though both are subject to the same tax rules. Favorable tax provisions encourage corporations to modify their activities to claim greater tax benefits, but doing so is costly; so simply treating the resulting tax reduction as a lower effective tax rate overstates the true tax benefit. Another limitation of much accountingstyle evidence is that samples typically (though not in the Congressional Budget Office's study) include only profitable corporations, so studies often do not incorporate the tax consequences of losses, and in particular the generally asymmetric nature of corporate tax systems that tax gains but permit only incomplete deductions of losses. The asymmetric taxation of gains and losses, and other important features of corporate tax systems, are also typically not incorporated in comparisons of effective marginal tax rates on new investment projects. These comparisons commonly posit stylized investments and evaluate the extent to which corporate taxes introduce wedges between pretax and after-tax marginal products of capital. Such calculations offer incomplete measures of the investment effects of corporate taxation-not only because the calculations usually fail to incorporate important tax provisions but also because the tax treatment of other business inputs and receipts also affects the demand for capital. As a result, it can be considerably more informative to compare corporate tax systems based on their statutory rates adjusted for tax expenditures.

Large corporations account for most U.S. corporate income and corporate tax payments, but it is useful also to consider the relative tax burdens of smaller companies based in different countries. The World Bank reports annual information on the tax obligations that would be imposed on the same hypothetical small manufacturing company (with well-defined financial and operational characteristics) over the first two years of operation in each of 190 countries. The results consistently indicate that U.S. tax burdens are some of the highest among the OECD countries; and findings for 2017 (PwC and World Bank 2017) are that the hypothetical manufacturing firm, if based in the United States, would face an average tax rate of 28.1 percent, second only to New Zealand's 30.0 percent among the OECD countries. Although this exercise, strictly speaking, applies only to a single, very specific type of business entity, its results are likely to carry implications for many other businesses; and there is cross-country 
evidence (Djankov and others 2010) that these estimated tax rates are correlated with lower rates of business formation and investment.

There are two direct implications of high U.S. business tax burdens. The first is that, with its high tax rates and worldwide tax system, the United States is not in a competitive tax position to attract internationally mobile firms and economic activities. Firms that can readily choose the countries where they are based have incentives not to be taxed by the United States. This is most evident with corporate inversions, in which corporations undertake transactions designed to change their tax homes, leaving the United States for foreign countries with lower tax rates and territorial tax systems (Desai and Hines 2002). And the corporate inversion phenomenon is only the most obvious manifestation of a firm's tax-motivated choice of where to legally base itself. There is ample evidence that levels and locations of foreign direct investment are highly responsive to local tax rates (Desai, Foley, and Hines 2004b; Hebous, Ruf, and Weichenrieder 2011), and that multinational firms based in countries with worldwide tax systems and high tax rates are less capable than other firms of competing for foreign investment in low-tax countries (Hines 1996; Barrios and others 2012). The international effects of the current U.S. tax system are therefore to discourage investment in the United States relative to other countries, and to reduce the extent to which U.S.-based firms invest in other countries.

The second, and even more direct, implication of high U.S. tax burdens is that the U.S. tax system discourages domestic business activity in the United States, and does so to a greater degree than do the tax systems of other countries. High corporate tax rates reduce rates of business formation and levels of capital investment (Da Rin, Di Giacomo, and Sembenelli 2011; Bond and Xing 2015; House, Mocanu, and Shapiro 2017), which, by depressing economic output and labor demand, thereby reduce living standards. Peter Diamond and James Mirrlees (1971a, 1971b) call attention to the inefficiency of taxing business income when governments have sufficient alternative tax instruments available, because it is possible to obtain the same tax revenue at lower net cost by imposing taxes directly on individuals rather than indirectly via business taxes whose costs individuals ultimately bear. In the Diamond-Mirrlees framework, individual taxation is more efficient than business taxation, notwithstanding the fact that individual taxes reduce incentives for income production; the point of their analysis is that business taxes similarly reduce incentives for individual income production by depressing pretax real wages-and business taxes, in addition, discourage business activity. Because the magnitude of the 
inefficiency increases with the size of business tax burdens, it follows that the United States has the potential to significantly improve the efficiency of its tax system by reducing its business taxes and obtaining needed revenue from other sources.

\section{The Structure of Business Taxation}

Business taxes affect incentives for business formation, expansion, and operation, which is why reforming poorly structured business taxes offers the prospect of improving resource allocation. Efficient business taxation minimizes the harmful consequences of taxation, albeit in a decidedly second-best fashion, because virtually any effort to collect tax revenue from the business sector distorts the economy. Conditional on raising any given amount of business tax revenue, efficient business taxes align private incentives with social costs and benefits, adjust for market failures, and seek to impose the heaviest tax burdens on activities that are least responsive to taxation.

An efficient business tax system will impose tax burdens that differ based on the nature of business activity, because activities are associated to differing degrees with socially beneficial or harmful spillovers, and generally differ in the extent to which they respond to taxation. For example, business $\mathrm{R} \& \mathrm{D}$ is commonly thought to stimulate economic productivity to a degree not entirely captured by firms doing the $\mathrm{R} \& \mathrm{D}$, which is why governments encourage greater levels of $R \& D$ by offering $R \& D$ tax credits and immediate deductibility of 100 percent or more of R\&D expenditures (Rao 2016). Analogously, efficient tax systems impose higher rates of taxation to discourage environmental pollution and other activities with negative externalities. To the extent that some firms operate in imperfectly competitive markets, the implied efficient adjustment is to reduce their taxes in order to stimulate greater output (Auerbach and Hines 2003), notwithstanding the oligopolistic profits that these firms earn and the need to raise other taxes in order to compensate for lower taxes on firms in oligopolistic markets, because the inefficiency created by imperfect competition takes the form of restricted output.

In addition to correcting for economic spillovers and market failures, efficient business taxes impose burdens that differ across activities, firms, and industries based on the extent to which they respond to taxation. Most OECD countries, and all major capital-exporting countries other than the United States, exempt from home country taxation all or virtually all the foreign incomes of their resident businesses. There are two efficiency-based 
reasons for exempting foreign income from home country taxation; the first is the highly tax-sensitive nature of foreign direct investment, and the second is the potential efficiency cost of distorting patterns of capital asset ownership (Desai and Hines 2003). One practical concern about the United States adopting a territorial tax system that would exempt foreign income from U.S. taxation is that such a change would offer greater encouragement for U.S. taxpayers to relocate taxable income from the United States to low-tax foreign countries. There is considerable controversy about the current extent of tax-motivated international income reallocation, and therefore the degree to which it might increase with the adoption of territorial taxation, though recent evidence (Dharmapala 2014; Hines 2014) suggests that the magnitude of this problem is quite modest.

In addition to exempting foreign income from taxation, efficient business taxes would distinguish tax burdens by industry, for example by imposing lighter tax burdens on mobile manufacturing activity than on relatively less mobile service activity-a function that is currently partially served in the United States by the domestic production activities deduction, which permits an additional deduction of 9 percent of manufacturing income. Capital investment incentives-in the form of current U.S. bonus depreciation, which permits firms to deduct 50 percent of the expense of eligible equipment investment, and of the rapid depreciation of other investment expenses-encourage economic activity by firms in capital-intensive industries and lines of business, implicitly at the expense of firms in other industries and lines of business. Similarly, to the extent that levels of investments that are more readily debt financed are themselves more responsive to taxation than other typical business investments, it follows that an efficient tax system would offer more generous treatment to interest expenses than to the cost of equity finance.

It is useful to consider more specifically the incentives created by business taxes. These taxes reduce after-tax business receipts and also reduce after-tax costs, because businesses are entitled to deduct at least a portion of costs against their taxable incomes. Consider the case in which a firm produces output with the production function $q(\mathbf{x})$, in which $\mathbf{x}$ is a vector of $n$ inputs, purchased at input price vector $\mathbf{p}$, and output $q$ is defined to have a price of 1. Firms are permitted to deduct a portion $\alpha_{i}$ of the cost of each input $i$, whereas all the firm's output is taxable, as a result of which the firm's after-tax profits are given by

$$
(1-\tau) q(\mathbf{x})-\sum_{i=1}^{n}\left(1-\tau \alpha_{i}\right) p_{i} x_{i}
$$


The first-order condition corresponding to the profit-maximizing interior choice of each input is then obtained by differentiating equation 10 with respect to $x_{i}$ :

$$
\frac{\partial q(\mathbf{x})}{\partial x_{i}}=\frac{1-\tau \alpha_{i}}{1-\tau} p_{i}
$$

Equation 11 is a standard expression of the effect of income taxes on input demands. For example, in the case of fully deductible expenses, such as normal wages and salaries paid by a profitable firm, $\alpha_{i}=1$ and equation 11 simplifies to $\frac{\partial q(\mathbf{x})}{\partial x_{i}}=p_{i}$, which indicates that the firm hires labor up to the point that its pretax marginal product equals the pretax cost of an additional unit of labor input. In the case of equity-financed capital investment, the one-period pretax cost of a unit of capital is $(r+\delta)$, in which $r$ is the firm's discount rate and $\delta$ is the depreciation rate of capital, $\alpha_{i}=z$, the present discounted value of depreciation allowances, and equation 11 implies that $\frac{\partial q(\mathbf{x})}{\partial x_{i}}=\frac{1-\tau z}{1-\tau}(r+\delta)$, a version of Robert Hall and Dale Jorgenson's (1967) familiar formula for the after-tax cost of capital.

In practice, there are many circumstances when input demands, as expressed in equation 11, are captured by values of $\alpha_{i}$ that are above or below 1, with capital investment being the obvious example but by no means the only important case. There are restrictions on the ability of taxpayers to claim deductions for expenses, the most important being the inability of loss-making firms to claim deductions for all their expenses. This arises because the tax system is asymmetric, and thus business profits are taxable but taxpayers are seriously limited in being able to claim refunds for tax losses. A firm that incurs labor and materials expenses of $\$ 1$ million in year 1 in order to obtain sales receipts of $\$ 1.5$ million in year 3 is permitted to carry forward its year 1 loss of $\$ 1$ million to reduce its year 3 taxable income to $\$ 0.5$ million, which thereby effectively permits the firm to deduct its year 1 expense (albeit without an adjustment for the time value of money). If instead of having certain sales of $\$ 1.5$ million in year 3 , the otherwise risk-neutral firm had a 50 percent chance of receiving $\$ 0$ in year 3 and a 50 percent chance of receiving $\$ 3$ million, the firm would either owe taxes on $\$ 2$ million of profits or be untaxed, thereby effectively enjoying the benefits of cost deductibility only half the time, corresponding to a value of $\alpha_{i}$ equal to roughly 0.5 . Given the large and growing magnitude of nonrefundable U.S. corporate tax losses relative to taxable 
U.S. corporate profits (Altshuler and others 2009; Patel and McClelland 2017), it follows that, in expectation, the expenses of representative U.S. firms are only partially deductible. This system effectively imposes higher tax burdens on firms that are less certain to be profitable and therefore can claim the full value of their tax deductions; such a pattern is consistent with efficient taxation if the activities of these firms are less tax-responsive than others, and quite inconsistent with efficiency if they are equally or more tax-responsive.

Equation 11 describes a set of input demands as functions of $\tilde{\mathbf{p}}$, the vector of tax-adjusted input prices that appear on the right side of equation 11. More generally, the vector of input demands can be written as $\mathbf{x}(q, \tilde{\mathbf{p}})$, reflecting the fact that input demand is a function of a firm's chosen output level — and that, for any given quantity of output, the firm's choice of inputs is a function of relative after-tax prices. To explain the effect of specific tax provisions, it is helpful to decompose their effects on input demands into substitution and scale-of-operation effects. The effect of a change in the tax price of input $i$ on demand for this input is given by

$$
\frac{d x_{i}(q, \tilde{\mathbf{p}})}{d \tilde{p}_{i}}=\frac{\partial x(q, \tilde{\mathbf{p}})}{\partial \tilde{p}_{i}}+\frac{\partial x(q, \tilde{\mathbf{p}})}{\partial q} \frac{d q}{d \tilde{p}_{i}} .
$$

Equation 12 illustrates that changes in the tax price of an input affect demand for this input in two ways: by encouraging input substitution at any given output level, and by changing the production levels of firms using the input more and less intensively. Thus, the research tax credit stimulates $R \& D$, both by encouraging firms to select $R \& D$-intensive processes to produce any given level of output, and by subjecting $R \& D$-intensive firms to lower tax rates than other firms, thereby expanding their scales of output - and there is no presumption about which of these two channels has the greater effect on total $R \& D$.

Efficiency-minded tax reform selects both the level and design of business taxes. The high current rates of U.S. business taxation imply that economic gains will be available if U.S. business taxes are reduced and other, more efficient taxes are used to recoup the lost revenue. The distributional consequences of such a change would of course depend on the specific nature of any business tax reductions and on which other taxes were used to raise the needed revenue; but with a progressive individual income tax at its disposal, the U.S. government could make this combination of tax changes more or less progressive than current taxes. In addition to adjusting the level of business taxation, a tax reform intended to improve economic 
efficiency would maintain and in some cases increase the differentiation of tax burdens across business activities, firms, and industries, notably by exempting the foreign incomes of U.S. firms, but more generally by offering favorable tax treatment to highly responsive economic activity.

ACKNOWLEDGMENTS I thank Alan Auerbach, Connor Cole, Peter Merrill, Joel Slemrod, James Stock, and participants in the Fall 2017 Brookings Panel on Economic Activity for helpful comments on a draft of this paper. 


\section{References}

Altshuler, Rosanne, Alan J. Auerbach, Michael Cooper, and Matthew Knittel. 2009. "Understanding U.S. Corporate Tax Losses." Tax Policy and the Economy 23: 73-122.

Astarita, Caterina, Lovise Bauger, Serena Fatica, Athena Kalyva, Gilles Mourre, and Florian Wohlbier. 2014. "Tax Expenditures in Direct Taxation in EU Member States." Occasional Paper no. 207. Brussels: European Commission.

Auerbach, Alan J., and James R. Hines Jr. 2003. "Perfect Taxation with Imperfect Competition." In Public Finance and Public Policy in the New Century, edited by Sijbren Cnossen and Hans-Werner Sinn. MIT Press.

Barrios, Salvador, Harry Huizinga, Luc Laeven, and Gaëtan Nicodème. 2012. "International Taxation and Multinational Firm Location Decisions." Journal of Public Economics 96, nos. 11-12: 946-58.

Bond, Stephen, and Jing Xing. 2015. "Corporate Taxation and Capital Accumulation: Evidence from Sectoral Panel Data for 14 OECD Countries." Journal of Public Economics 130: 15-31.

Congressional Budget Office. 2017. "International Comparisons of Corporate Income Tax Rates.” Washington. https://www.cbo.gov/publication/52419

Da Rin, Marco, Marina Di Giacomo, and Alessandro Sembenelli. 2011. "Entrepreneurship, Firm Entry, and the Taxation of Corporate Income: Evidence from Europe." Journal of Public Economics 95, nos. 9-10: 1048-66.

Desai, Mihir, Dhammika Dharmapala, and Monica Singhal. 2010. "Tax Incentives for Affordable Housing: The Low Income Housing Tax Credit." Tax Policy and the Economy 24: 181-205.

Desai, Mihir A., C. Fritz Foley, and James R. Hines Jr. 2004a. “A Multinational Perspective on Capital Structure Choice and Internal Capital Markets." Journal of Finance 59, no. 6: 2451-87.

. 2004b. "Foreign Direct Investment in a World of Multiple Taxes." Journal of Public Economics 88, no. 12: 2727-44.

- 2016. "Trade Credit and Taxes." Review of Economics and Statistics 98, no. 1: 132-39.

Desai, Mihir A., and James R. Hines Jr. 2002. "Expectations and Expatriations: Tracing the Causes and Consequences of Corporate Inversions." National Tax Journal 55, no. 3: 409-40.

2003. "Evaluating International Tax Reform." National Tax Journal 56, no. 3: 487-502.

Dharmapala, Dhammika. 2014. "What Do We Know about Base Erosion and Profit Shifting? A Review of the Empirical Literature." Fiscal Studies 35, no. 4: 421-48.

Diamond, Peter A., and James A. Mirrlees. 1971a. "Optimal Taxation and Public Production I: Production Efficiency." American Economic Review 61, no. 1: $8-27$.

1971b. "Optimal Taxation and Public Production II: Tax Rules." American Economic Review 61, no. 3: 261-78. 
Djankov, Simeon, Tim Ganser, Caralee McLiesh, Rita Ramalho, and Andrei Shleifer. 2010. "The Effect of Corporate Taxes on Investment and Entrepreneurship." American Economic Journal: Macroeconomics 2, no. 3: 31-64.

Graham, John R. 1996. "Debt and the Marginal Tax Rate." Journal of Financial Economics 41, no. 1: 41-73.

2000. "How Big Are the Tax Benefits of Debt?" Journal of Finance 55, no. 5: 1901-41.

Hall, Robert E., and Dale W. Jorgenson. 1967. "Tax Policy and Investment Behavior." American Economic Review 57, no. 3: 391-414.

Hebous, Shafik, Martin Ruf, and Alfons J. Weichenrieder. 2011. "The Effects of Taxation on the Location Decision of Multinational Firms: M\&A versus Greenfield Investments." National Tax Journal 64, no. 3: 817-38.

Hines, James R., Jr. 1996. "Altered States: Taxes and the Location of Foreign Direct Investment in America." American Economic Review 86, no. 5: 1076-94.

- 2014. "How Serious Is the Problem of Base Erosion and Profit Shifting?" Canadian Tax Journal 62, no. 2: 443-53.

House, Christopher L., Ana-Maria Mocanu, and Matthew D. Shapiro. 2017. "Stimulus Effects of Investment Tax Incentives: Production versus Purchases." Working Paper no. 23391. Cambridge, Mass.: National Bureau of Economic Research.

Jordan, Bradford D., and Richard H. Pettway. 1985. "The Pricing of Short-Term Debt and the Miller Hypothesis: A Note." Journal of Finance 40, no. 2: 589-94.

Markle, Kevin S., and Douglas A. Shackelford. 2012. "Cross-Country Comparisons of Corporate Income Taxes." National Tax Journal 65, no. 3: 493-528.

— 2014. "The Impact of Headquarter and Subsidiary Locations on Multinationals' Effective Tax Rates." Tax Policy and the Economy 28: 33-62.

OECD (Organization for Economic Cooperation and Development). 2010. Tax Expenditures in OECD Countries. Paris.

Patel, Elena, and John McClelland. 2017. "What Would a Cash-Flow Tax Look Like for U.S. Companies? Lessons from a Historical Panel." Working Paper no. 116. Washington: U.S. Department of the Treasury, Office of Tax Analysis.

PwC and World Bank. 2017. Paying Taxes 2017. London and Washington. https:// www.pwc.com/gx/en/paying-taxes/pdf/pwc-paying-taxes-2017.pdf

Rao, Nirupama. 2016. "Do Tax Credits Stimulate R\&D Spending? The Effect of the R\&D Tax Credit in Its First Decade." Journal of Public Economics 140: 1-12.

Surrey, Stanley S. 1973. Pathways to Tax Reform: The Concept of Tax Expenditures. Harvard University Press. 